\title{
16. LATE NEOGENE PALEOCEANOGRAPHY IN THE WESTERN NORTH PACIFIC ${ }^{1}$
}

\author{
Itaru Koizumi, Institute of Geological Sciences, Osaka University²
}

\begin{abstract}
Late Neogene paleoceanographic history in the western North Pacific is discussed on the basis of: (1) Td (diatom temperature) values, (2) species composition, and (3) the structure of diatom assemblages at Sites 579 and 580 . These factors provide a record of fluctuations of the past position of the subarctic-subtropic front because these sites lie within the transition zone between the modern day subarctic and central water masses. Changes in species composition during the past $4.0 \mathrm{~m} . \mathrm{y}$. are recognized. Major paleoclimatic events are discussed on the basis of Td values. Distinct, large drops in surface water temperature, estimated on the basis of Td values, occurred $2.5,2.0$, and $1.6 \mathrm{~m} . \mathrm{y}$. ago. Large fluctuations of surface water temperature are recognized throughout the recovered sediments. The preglacial/glacial boundary occurs $2.50-2.85 \mathrm{~m}$.y. ago at $40^{\circ} \mathrm{N}$ in the western North Pacific.
\end{abstract}

\section{INTRODUCTION}

The primary objective of Deep Sea Drilling Project (DSDP) Leg 86 was to unravel the late Neogene paleoceanographic history in the western North Pacific by establishing a north-south transect across the Kuroshio Current system. At both Sites 579 and 580, thick sections of Pleistocene and Pliocene biosiliceous clay and ooze were recovered in the transition zone between the modern subarctic and central water masses (Fig. 1). Sediments from both sites are homogeneous in color and texture. These sediments lack any depositional sedimentary structures, although the sediments from Site 579 are burrow mottled. Diatoms are abundant and well preserved throughout much of these sections (see Koizumi and Tanimura, this volume).

The western North Pacific Ocean is divided into three different marine environments (Fig. 1): (1) the subarctic region containing the subarctic water mass, (2) the subtropic region containing the central water mass, and (3) the transition region, which is a mixed zone of both subarctic and central water masses (Fig. 1). The subarctic region is characterized by an annual precipitation that exceeds evaporation and by cold, low salinity surface water. A permanent halocline extends between 100 and $200 \mathrm{~m}$ below the sea surface. The subtropic region is characterized by a high annual evaporation that exceeds precipitation. The surface water salinity maximum decreases to a minimum between 500 and $600 \mathrm{~m}$ below the sea surface. The transition region located between the subarctic and subtropic regions lies between 40 and $42^{\circ} \mathrm{N}$ latitude. This region is at the $34 \% 0$ isohaline and coincides with the line along which evaporation equals precipitation (Dodimead et al., 1963). Transition region water is derived from off the coast of Japan, where the cold Oyashio Current, originating in the Bering Sea and

\footnotetext{
${ }^{1}$ Heath, G. R., Burckle, L. H., et al., Init. Repts. DSDP, 86: Washington (U.S. Govt. Printing Office).

2 Address: Institute of Geological Sciences, College of General Education, Osaka University, Toyonaka, Osaka 560, Japan.
}

the Sea of Okhotsk, converges with the warm Kuroshio Current, originating in the central water mass (Fig. 1). The mixed surface water moves eastward across the Pacific in the West Wind Drift.

Concentration of nutrient salts in the surface waters is higher in the subarctic region than in the subtropic region. Upwelling of nutrient-rich deep water occurs near the center of the gyres in the subarctic region. Primary productivity in the subarctic region is, therefore, greater than in the subtropic region.

Site 579 lies near the southern margin of the transition zone between the subarctic and subtropic water masses, and its sediments should therefore provide a record of extreme southerly excursions of the subarctic-subtropic front. Site 580 lies near the northern margin of the transition zone, and its sediments should provide a record of northward fluctuations of the position of this front.

Donahue (1970) discussed Pleistocene climatic changes on the basis of Td values (Kanaya and Koizumi, 1966) in several northern North Pacific piston cores for which a paleomagnetic time scale is available. The paleoceanographic history of the western North Pacific has not been extended back through the Pliocene. This is the result of a lack of complete sections, since piston corers cannot recover a complete Pliocene section in this region of the North Pacific, where sedimentation rates are relatively high.

Major paleoclimatic and paleoceanographic events have, however, been identified by delineating planktonic foraminiferal biofacies in DSDP cores from the subtropic region (e.g., Vincent, 1975; Keller, 1979) and by establishing oxygen isotope records in both equatorial piston cores (e.g., Shackleton and Opdyke, 1976, 1977) and DSDP cores from the subtropic region of the eastern North Pacific (e.g., Keigwin, 1979).

The Pliocene/Pleistocene boundary is conventionally placed at the top of the Olduvai Event (Burckle and Opdyke, 1977). The early/late Pliocene boundary is placed at about 3.0 m.y. ago (at the base of the Kaena Event); the early/late Pleistocene boundary is at about $0.9 \mathrm{~m}$.y. ago (at the top of the Jaramillo Event). 


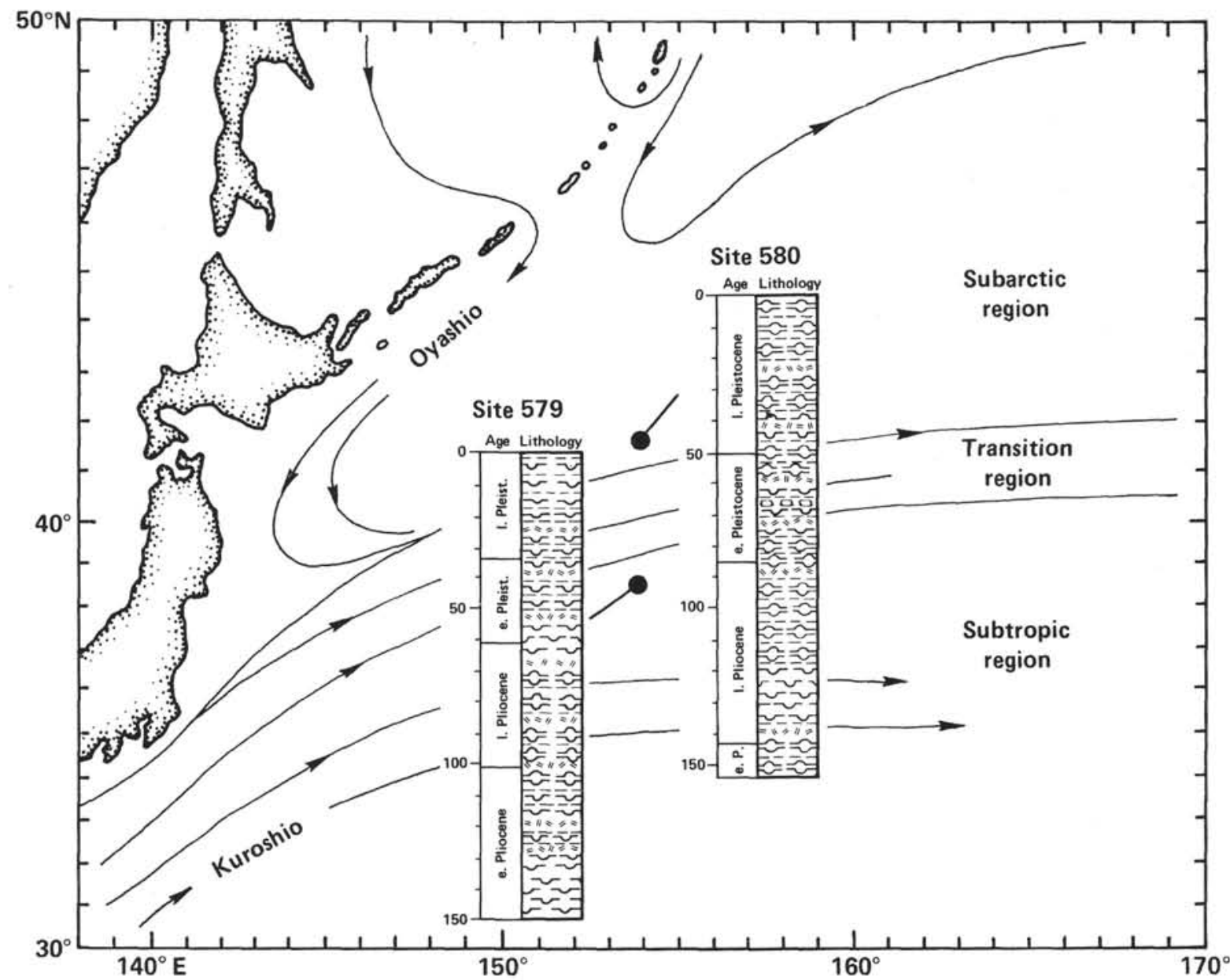

Figure 1. Location and schematic lithologic sections of Sites 579 and 580 studied on DSDP Leg 86 . Site locations are shown in relation to the three major ocean regions. Two holes were drilled at Site 579: Hole 579 lies at $38^{\circ} 37.68^{\prime} \mathrm{N}, 153^{\circ} 50.17^{\prime} \mathrm{E}$, depth $5737 \mathrm{~m}$; Hole $579 \mathrm{~A}$ at $38^{\circ} 37.61^{\prime} \mathrm{N}, 153^{\circ} 50.28^{\prime} \mathrm{E}$, depth $5737 \mathrm{~m}$. Site 580 is located at $41^{\circ} 37.47^{\prime} \mathrm{N}, 153^{\circ} 58.58^{\prime} \mathrm{E}$, depth $5375 \mathrm{~m}$.

This study extends the work of Donahue (1970) back into the Pliocene in a north-south transect across the transition zone of the western North Pacific.

\section{MATERIALS}

Samples were taken one per section (one per $150 \mathrm{~cm}$ ) throughout all the cores recovered at Sites 579 and 580 . A detailed chronology, developed through paleomagnetic studies, is available for each of these sections (Bleil, this volume). Age-depth profiles at Sites 579 and 580 indicate that the sedimentation rates increased in the late Pleistocene at both sites (Fig. 2). Sedimentation rates average about $4 \mathrm{~cm} / 10^{3}$ yr. at Site 579 , giving a sample spacing of about $38,000 \mathrm{yr}$. and about $5.4 \mathrm{~cm} / 10^{3} \mathrm{yr}$. at Site 580 , giving a sample spacing of about 28,000 yr. Sedimentation rates during the early Pleistocene and Pliocene are about $3.2 \mathrm{~cm} / 10^{3} \mathrm{yr}$. at Site 579 , giving rise to a sampling interval of $47,000 \mathrm{yr}$. and $4.4 \mathrm{~cm} / 10^{3} \mathrm{yr}$. at Site 580 , giving rise to a sampling interval of $34,000 \mathrm{yr}$.

\section{METHOD OF STUDY}

Paleoceanographic analysis is undertaken in this chapter on the basis of: (1) Td values, (2) species composition in a given assemblage, and (3) assemblage structure. Td variations are the primary indicator of paleoclimatic events.

\section{Td (diatom temperature) Values}

The Td statistic was proposed by Kanaya and Koizumi (1966) to estimate surface water temperature during the accumulation of sediments in the lower levels of a core sequence. Td is defined as (Xw/Xw $+\mathrm{Xc}) \times 100$, where $\mathrm{Xw}$ is the frequency of warm-water diatoms and $\mathrm{Xc}$ is that of cold-water diatoms. Xw and Xc species have been selected according to Kanaya and Koizumi (1966; Table 1). All these diatoms are living species. Td ranges in value from 0 to 100 . Going from the subarctic region to the tropic region, Td becomes systematically larger (Kanaya and Koizumi, 1966, fig. 5). Namely, Td values show (in a broad sense) a positive correlation with surface water temperature over a given geographical site in the North Pacific. Correlation of the uppermost sediment $\mathrm{Td}$ values with surface water temperature at both Sites 579 and 580 is used to estimate surface water temperature from downhole $\mathrm{Td}$ values at both sites (Fig. 3).

\section{Species Composition}

1. Selected Species. Quantitative distribution of selected species from the members of $\mathrm{Xw}$ and $\mathrm{Xc}$ in the $\mathrm{Td}$ formula is examined. Coscinodiscus nodulifer was chosen as a representative of the central water mass (Xw) and Denticulopsis seminae as a representative of the subarctic water mass $(\mathrm{Xc})$. C. nodulifer has been classified as a subtropic or tropic (i.e., "warm-water") species in other investigations (e.g., Jousé et al., 1971; Hasle, 1976). D. seminae has been classified 


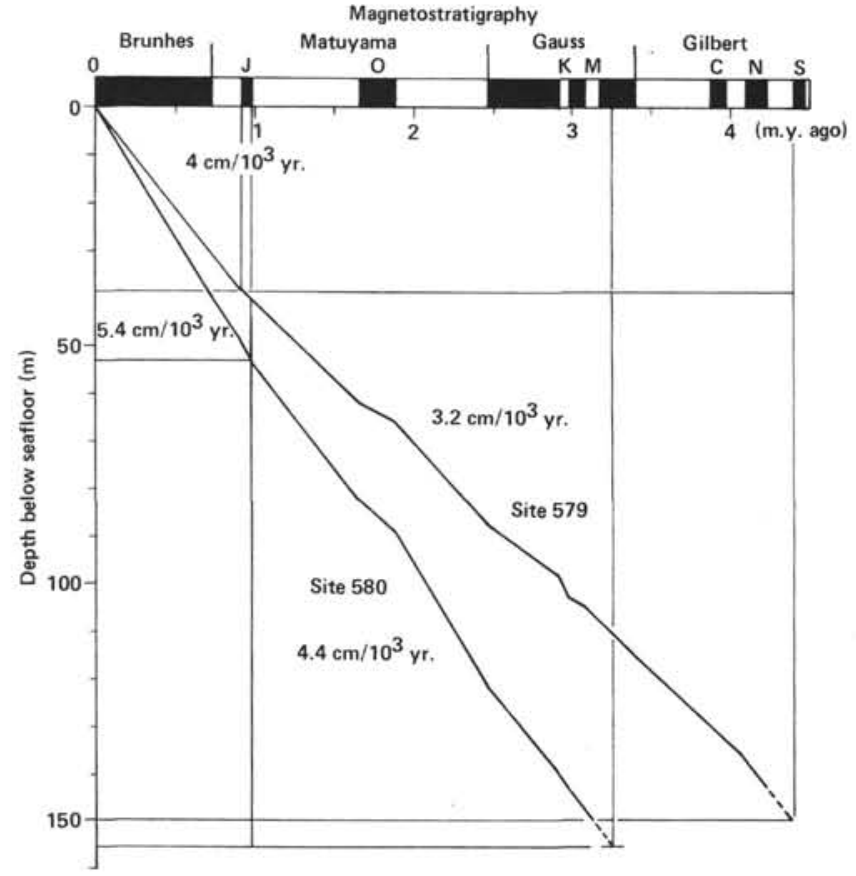

Figure 2. Age-depth plot for Sites 579 and 580. Age is based on magnetostratigraphy (Bleil, this volume). Late Pleistocene sedimentation rates average about $4 \mathrm{~cm} / 10^{3} \mathrm{yr}$. at Site 579 and about $5.4 \mathrm{~cm}$ / $10^{3} \mathrm{yr}$. at Site 580 . Sedimentation rates decrease to about $3.2 \mathrm{~cm} /$ $10^{3} \mathrm{yr}$. at Site 579 and $4.4 \mathrm{~cm} / 10^{3} \mathrm{yr}$. at Site 580 during the early Pleistocene and Pliocene. See legend of Figure 4 for definition of magnetostratigraphic events.

as "cold-water" (Hasle, 1976) and as "subarctic" (Venrick, 1971) in the North Pacific. The relative frequency of occurrence of these two species changes significantly in the transition zone between the modern subarctic and central water masses.

2. Recurrent Group. Kanaya and Koizumi (1966) determined recurrent groups by using joint occurrences of diatoms that have habitats in the water column of the North Pacific. Group I is composed of planktonic diatoms known to inhabit subtropic and tropic waters, Group II is composed of oceanic diatoms of the boreal zone occurring in subarctic waters, and Group IV is limited to arctic and arctoboreal neritic diatoms. Their species composition at Sites 579 and 580 is given in Table 1.

According to the distribution patterns of recurrent groups (Kanaya and Koizumi, 1966, fig. 4), both Groups I and II are identified within the geographic range of the transition zone. The distribution of Group IV closely coincides with the path of the cold Oyashio Current. Therefore, at all stations where Group IV is identified, Group II is also recognized.

Downhole variations in abundances of Group I and Group II diatoms at Sites 579 and 580 are examined to determine which group was dominant at various geologic times in the transition zone. A discussion of abundance variations of Group IV diatoms follows.

\section{Assemblage Structure}

1. Number of Diatoms. Jousé et al. (1971) counted diatoms per gram in surface sediments of the Pacific Ocean. The number of diatoms in a given volume of sediments depends on (1) preservation and/ or dissolution of the diatoms, (2) dilution with terrigenous and/or other organic materials, and (3) diatom productivity. As expected, the number of diatoms in surface sediments varies considerably in different regions of the Pacific Ocean. High diatom concentrations of $2.5-5.0 \times 10^{7} / \mathrm{g}$ occur in the transition region of the western North Pacific, but in most areas the concentration is less than $2.5 \times 10^{7} / \mathrm{g}$ (Jousé et al., 1971). Quantitative analysis of the number of diatoms examined in this study resulted in much higher diatom concentrations values than those estimated by Jousé et al. (1971).
Table 1. Species composition of cold-water diatoms, warmwater diatoms, and recurrent groups.

Cold-water diatoms $(\mathrm{Xc})$

Actinocyclus curvatulus Janisch

Actinocyclus ochotensis Jousé

Asteromphalus robustus Castracane

Bacteriosira fragilis (Gran) Gran

Chaetoceros furcellatus Bailey

Coscinodiscus marginatus Ehrenberg

Coscinodiscus oculus-iridis Ehrenberg

Denticulopsis seminae (Simonsen and Kanaya) Simonsen

Nitzschia cylindrus (Grunow) Hasle

Odontella aurita (Lyngbye) Agardh

Porosira glacialis (Grunow) Jørgensen

Rhizosolenia hebetata forma hiemalis (Bailey) Gran

Thalassiosira gravida Cleve

Thalassiosira hyalina (Grunow) Gran

Thalassiosira kryophila (Grunow) Goerg

Thalassiosira nordenskioldii Cleve

Thalassiosira trifulta Fryxell

Warm-water diatoms (Xw)

Coscinodiscus africanus Janisch

Coscinodiscus nodulifer Schmidt

Coscinodiscus perforatus Ehrenberg

Hemidiscus cuneiformis Wallich

Nitzschia marina Grunow

Planktoniella sol (Wallich) Schütt

Pseudoeunotia doliolus (Wallich) Grunow

Rhizosolenia bergonii Peragallo

Ropertia tesselata (Roper) Grunow

Thalassiosira leptopus (Grunow) Hasle and Fryxell

Thalassiosira lineata Jousé

Group I (Subtropic diatoms)

Coscinodiscus africanus Janisch

Coscinodiscus nodulifer Schmidt

Coscinodiscus perforatus Ehrenberg

Coscinodiscus tabularis Grunow var. egregius (Rattry) Hustedt Hemidiscus cuneiformis Wallich

Nitzschia marina Grunow

Planktoniella sol (Wallich) Schütt

Pseudoeunotia doliolus (Wallich) Grunow

Rhizosolenia bergonii Peregallo

Roperia tesselata (Roper) Grunow

Thalassionema nitzschioides Grunow

Thalassionema nitzschioides Grunow vars.

Thalassiosira decipiens (Grunow) Jorgensen

Thalassiosira eccentrica (Ehrenberg) Cleve

Thalassiosira leptopus (Grunow) Hasle and Fryxell

Thalassiosira lineata Jousé

Thalassiosira oestrupii (Ostfeld) Proskina-Lavrenko

Group II (Subarctic diatoms)

Actinocyclus curvatulus Janisch

Actinocyclus ochotensis Jousé

Asteromphalus robustus Castracane

Coscinodiscus marginatus Ehrenberg

Coscinodiscus oculus-iridis Ehrenberg

Denticulopsis seminae (Simonsen and Kanaya) Simonsen

Odontella aurita (Lyngbye) Agardh

Rhizosolenia hebetata forma hiemalis (Bailey) Gran

Thalassiosira gravida Cleve

Thalassiosira trifulta Fryxell

Group IV (Arctic and arcto-boreal neritic diatoms)

Bacteriosira fragilis (Gran) Gran

Chaetoceros furcellatus Bailey

Nitzschia cylindrus (Grunow) Hasle

Porosira glacialis (Grunow) Jørgensen

Thalassiosira hyalina (Grunow) Gran

Thalassiosira kryophila (Grunow) Goerg

Thalassiosira nordenskioldii Cleve 

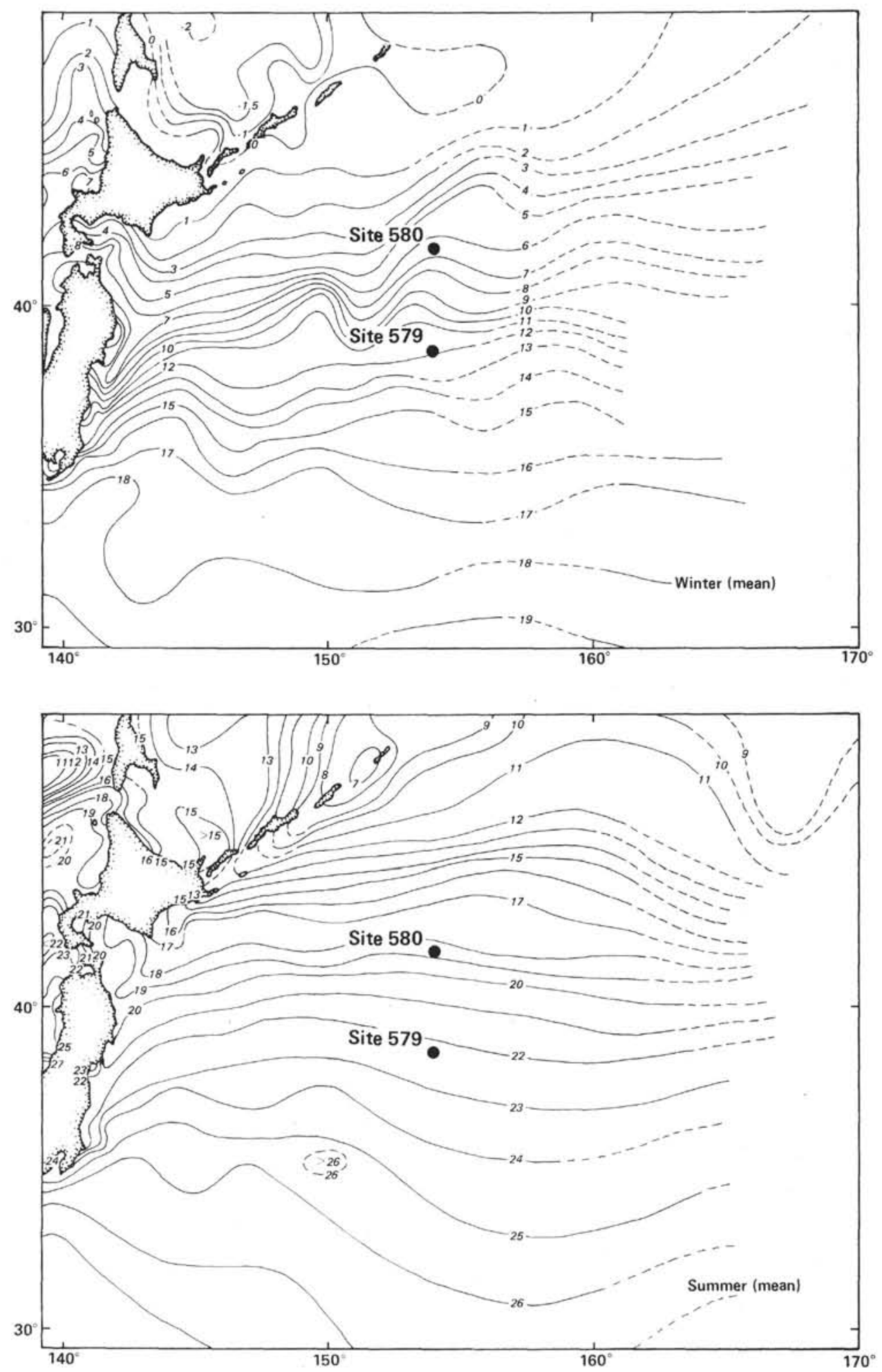

Figure 3. Location of Sites 579 and 580 in relation to surface water temperatures in winter and summer (Japan Oceanographic Data Center, 1978).

2. Productivity. A close relationship between high concentrations of Chaetoceros spores, high productivity, and intensive upwelling has been recognized in the surface sediments of the Bering and Okhotsk seas (Sancetta, 1982). On the basis of this observation, the number of Chaetoceros spores was examined in order to estimate the level of diatom productivity at Sites 579 and 580 .

3. Species Diversity. Characteristics of the assemblage structure, which should vary with changing environments, may be expressed by the diversification of species constituting the assemblages (Ikeya, 1971). A numerical diversity index showing the degree of balance in the structure of assemblages, Simpson's diversity index, was adopted in this study (Simpson, 1949). The diversity index is defined as

$$
N(N-1) \quad \sum_{i=1}^{S} n_{i}\left(n_{i}-1\right),
$$


where $N$ is total number of specimens, $s$ is total number of species, and $n_{i}$ is the number of specimens of the $i$ th species. This diversity index is high when the assemblage structure is complex or highly diversified and low when the structure is simple or less diversified.

\section{RESULTS OF PALEOCEANOGRAPHIC ANALYSIS}

\section{Td (diatom temperature) Value}

\section{Site 579}

Td values generally decrease from the bottom to the top of Site 579 (Fig. 4). This decrease probably indicates an overall decline in temperature toward the present day. This general trend is punctuated by large fluctuations in Td value throughout the section.

The high Td values observed in the lower Pliocene result both from the absence of cold-water diatoms, such as Denticulopsis seminae, and from the abundance of warm-water diatoms, such as Coscinodiscus nodulifer and Hemidiscus cuneiformis. A large decrease in Td value occurs during the upper Pliocene; late Pliocene Td values are lower than the present-day value for the site. This decrease in Td value occurs at about $100 \mathrm{~m}$ sub-bottom (between Cores 9 and 10) within the Kaena Event, coinciding with the lithologic change from a clayey diatom ooze to a clayey siliceous ooze. The sharp decrease in $\mathrm{Td}$ value at this point indicates the transition from a preglacial to glacial age. The first Td minimum, which is equivalent to the low $\mathrm{Td}$ values observed in the Brunhes Epoch, occurs between 67.76 and $71.00 \mathrm{~m}$ sub-bottom (Samples 579A-6-5, 25-26 cm to 579A-6,CC), below the Olduvai Event. The beginning of the Pleistocene is marked by a sharp drop in Td values occurring at about $60 \mathrm{~m}$ sub-bottom (from Sample 579A-5-6, 94-95 cm to Sample 579A-5-7, 25-26 cm). The Td curve is fairly stable, with only small fluctuations in the lower Pleistocene. The large $\mathrm{Td}$ fluctuations during the upper Pleistocene suggest repeated north-south shifts of the subarctic-subtropic front in response to climatic fluctuations. Remarkably high Td values occur in the interval from 17.15 to $23.15 \mathrm{~m}$ sub-bottom (Samples 579A-1-3, $13-14 \mathrm{~cm}$ to $579 \mathrm{~A}-1-7,13-14 \mathrm{~cm}$ ), indicative of a large interglacial stage.

\section{Site $\mathbf{5 8 0}$}

Fluctuations in the Td curve at Site 580 correlate very well with those at Site 579 (Fig. 5). Two sharp drops are apparent: one at about $140 \mathrm{~m}$ sub-bottom (Samples $580-16-2,83-84 \mathrm{~cm}$ to $580-16-4,83-84 \mathrm{~cm}$ ) within the Kaena Event and the other at about $121 \mathrm{~m}$ sub-bottom (Samples 580-14-1, 130-131 cm to 580-14-5, 130-131 cm) between the Matuyama and Gauss Epoch. Td values during the Matuyama and Brunhes Epoch are generally lower than the present value for Site 580, although high $\mathrm{Td}$ values occur at $102 \mathrm{~m}$ sub-bottom (Sample 580-12-3, $103-104 \mathrm{~cm}$ ), between the Olduvai Event and the Gauss/ Matuyama boundary, and at $29.52 \mathrm{~m}$ sub-bottom (Sample 580-4-5, 121-122 cm), in the lower part of the Brunhes Epoch. Nine Td minima are seen during the Brunhes Epoch, as indicated by Donahue (1970) in LDGO (Lamont-Doherty Geological Observatory) piston core
V20-108 $\left(45^{\circ} 27^{\prime} \mathrm{N}, 179^{\circ} 14^{\prime} \mathrm{W}\right)$. Donahue (1970) also discussed two major subdivisions of the Pleistocene on the basis of Td values in deep-sea cores from the North $\mathrm{Pa}$ cific: one from 1.7 to $0.7 \mathrm{~m}$.y. ago, which was a time of relatively stable $\mathrm{Td}$ values, the other from $0.7 \mathrm{~m} . \mathrm{y}$. ago to the present, which was a time of lower average Td values than in the former interval but of greater fluctuation.

Large fluctuations in Td value occur at Site 579. These fluctuations probably represent significant north-south shifts of the subarctic-subtropic front. Lower Td values with smaller fluctuations, on the other hand, are observed throughout most of Site 580. These Td shifts may reflect changes in the surface water temperature of the subarctic region.

\section{Species Composition}

\section{Site 579}

1. Selected Species. Coscinodiscus nodulifer is abundant in the lower part of the lower Pliocene, but its abundance sharply decreases coincident with the appearance of Denticulopsis seminae in the upper part of the Gilbert Epoch (Fig. 4). Upsection, C. nodulifer becomes a minor element in the assemblages. Fluctuations in the frequency of $D$. seminae mirror fluctuations in Td values during the upper Pliocene and Pleistocene. Two frequency peaks are seen: one at $9.64 \mathrm{~m}$ sub-bottom (Sample $579-2-1,123-124 \mathrm{~cm}$ ) and the other at $25.14 \mathrm{~m}$ subbottom (Sample 579A-2-2, 13-14 cm) in the Brunhes Epoch.

2. Recurrent Group. Group I is more abundant than Group II throughout the site, except for these three levels (Fig. 4): $59.76 \mathrm{~m}$ sub-bottom (Sample 579A-5-6, $25-26 \mathrm{~cm}$ ) just above the Olduvai Event, and 9.64 and $25.14 \mathrm{~m}$ sub-bottom as mentioned earlier.

The shape of the Group I abundance curve is similar to the Td value curve (i.e., decreasing toward the top of the site). Group IV appears at $53.76 \mathrm{~m}$ sub-bottom (Sample 579A-5-2, 25-26 cm), although absent between the Olduvai and Jaramillo events, but it is never more than a minor component in the assemblages.

\section{Site $\mathbf{5 8 0}$}

1. Selected Species. Coscinodiscus nodulifer is nil or scarce throughout the Pleistocene and is only slightly more abundant in the Pliocene (Fig. 5). Denticulopsis seminae shows large abundance fluctuations throughout the section (Fig. 5). The overall abundance of $D$. seminae is greatest in the lower Pleistocene and in the lower part of the upper Pleistocene. This variation in abundance is generally concordant with that of Group II, which is composed of subarctic diatoms (Table 1).

Two sharp abundance decreases of $D$. seminae are recognized: one at $26.52 \mathrm{~m}$ sub-bottom (Sample 580-4-3, $121-122 \mathrm{~cm}$ ) and the other at $4.59 \mathrm{~m}$ sub-bottom (Sample 580-2-1, 128-129 cm) in the Brunhes Epoch. At these two points, Group I, which is composed of the subtropic diatoms, is of greater abundance than Group II, but the assemblage is otherwise different. At the deeper point, decreases in the abundances of Group II diatoms, 


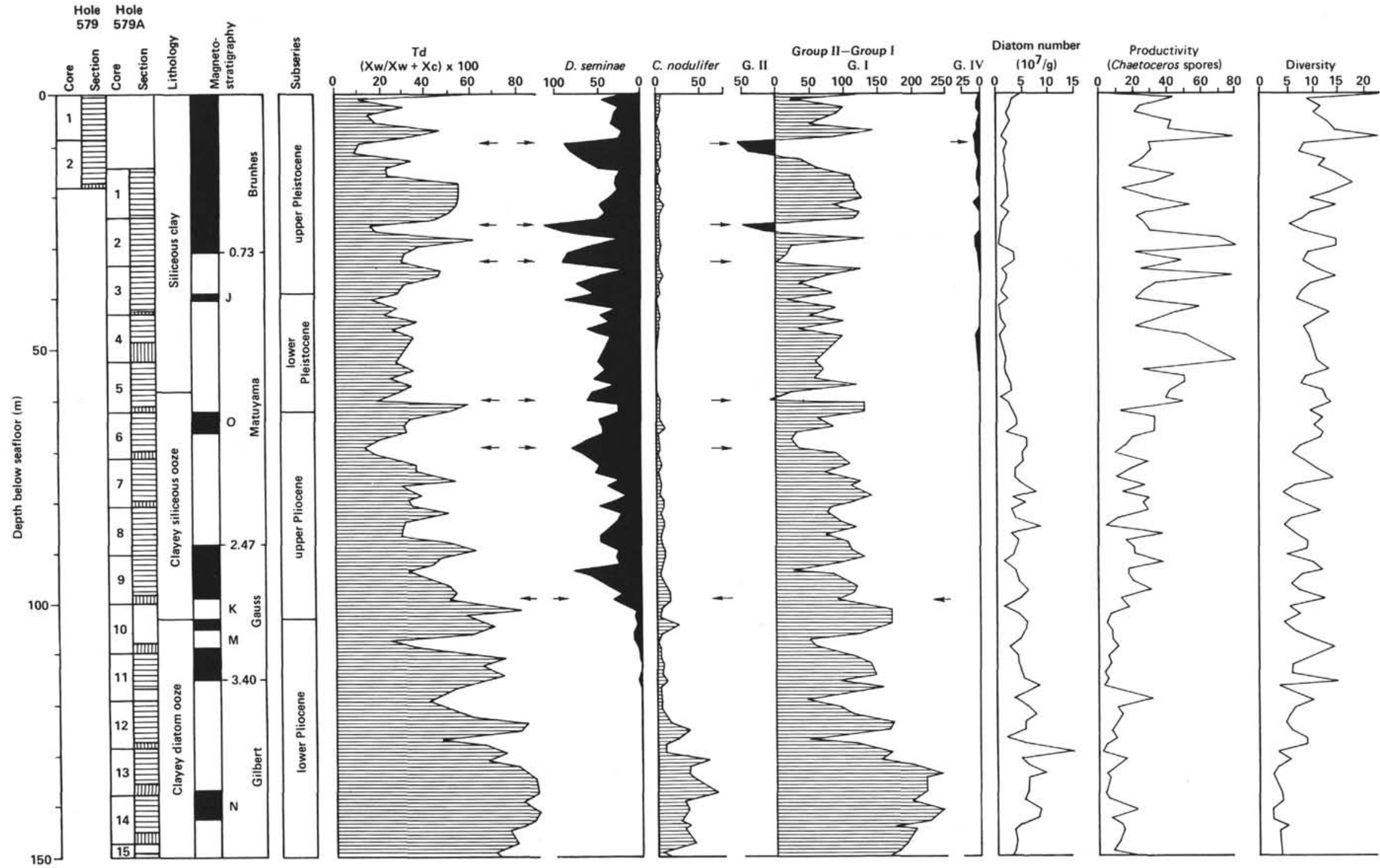

Figure 4. Site 579: Stratigraphic variations of Td (diatom temperature) values, frequencies of the cold-water diatom Denticulopsis seminae and the warm-water diatom Coscinodiscus nodulifer, discrepancies in frequencies between recurrent Groups I and II, frequencies of recurrent Group IV, concentration of diatoms, productivity on the basis of numbers of Chaetoceros spores, and Simpson's diversity index. Arrows indicate locations of major paleoceanographic changes as suggested by Td values and the composition of species as follows: $9.64 \mathrm{~m}$ sub-bottom (Sample 579 2-1, 123-124 cm), $25.14 \mathrm{~m}$ sub-bottom (Sample 579A-2-2, 13-14 cm), 32.64 m sub-bottom (Sample 579A-2-7, 13-14 cm), 59.76 m sub-bottom (Sample 579A-5-6, 25-26 cm), 67.76 m sub-bottom (Sample 579A-6-5, 25-26 cm), and about $100 \mathrm{~m}$ sub-bottom (between Samples 579A-9, CC and 579A-10,CC). Magnetostratigraphy: J = Jaramillo Event, O = Olduvai Event, K = Kaena Event, $\mathrm{M}=$ Mammoth Event, $\mathrm{C}=$ Cochiti Event, $\mathrm{N}=$ Nunivak Event, $\mathrm{S}=$ Sidufjall Event. 


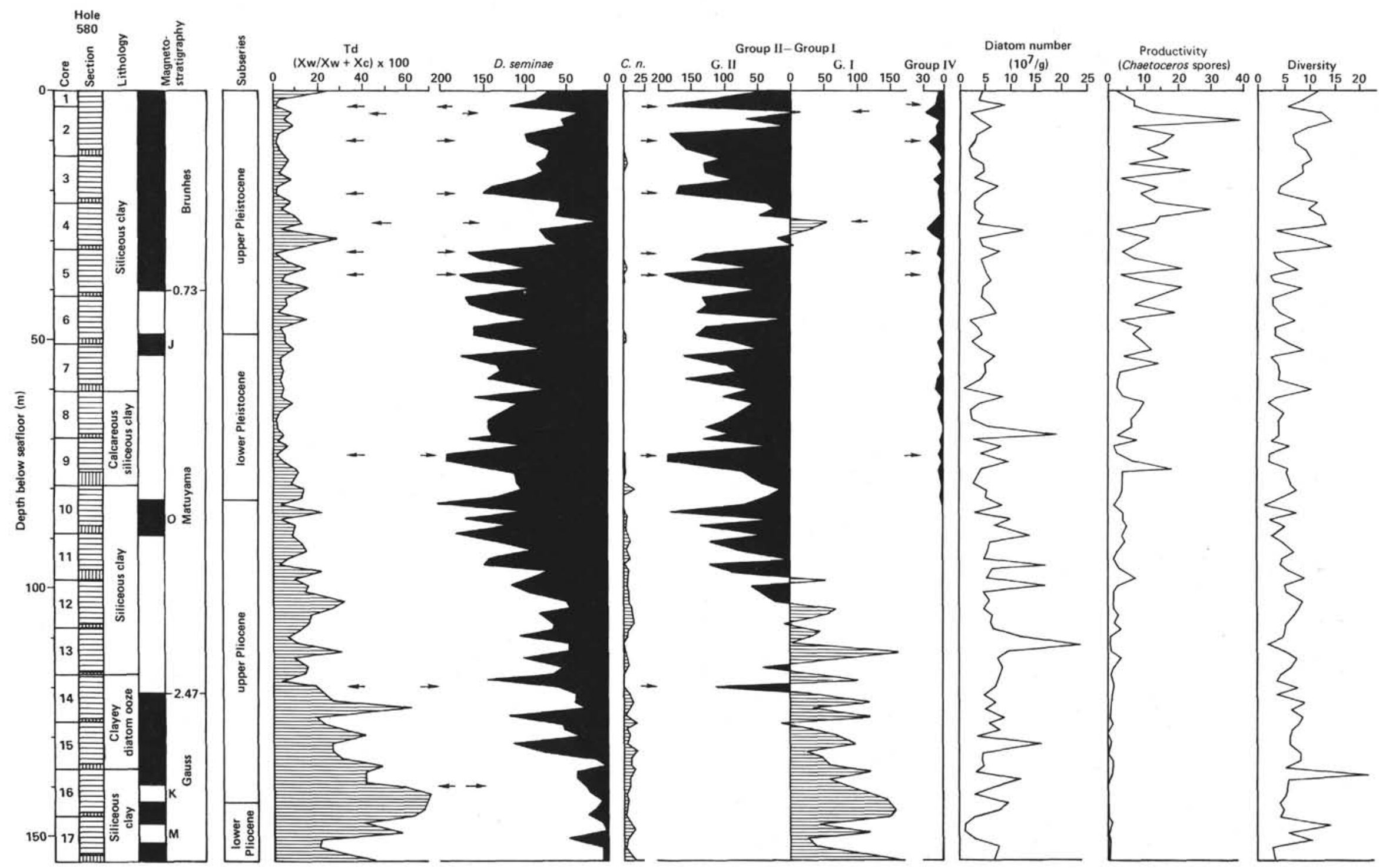

Figure 5. Site 580: Stratigraphic variations of Td (diatom temperature) values, frequencies of the cold-water diatom Denticulopsis seminae and the warm-water diatom Coscinodiscus nodulifer, discrepancies in frequencies between recurrent Groups I and II, frequencies of recurrent Group IV, concentration of diatoms, productivity on the basis of numbers of Chaetoceros spores, and Simpson's diversity index. Arrows indicate location of major paleoceanographic changes as suggested by Td values and the composition of species as follows: $3.02 \mathrm{~m}$ sub-bottom (Sample 580 1-3, 2-3 cm), $10.59 \mathrm{~m}$ sub-bottom (Sample 580-2-5, 128-129 cm), $26.52 \mathrm{~m}$ sub-bottom (Sample 580-4-3, 121-122 cm), $20.56 \mathrm{~m}$ sub-bottom (Sample 580-3-6, 25-26 cm), 32.21 m sub-bottom (Sample 580-5-1, 40-41 cm), 36.71 m sub-bottom (Sample 580-5-4, 40-41 cm), $73.04 \mathrm{~m}$ sub-bottom (Sample 580-9-3, 23-24 cm), 120.10 m sub-bottom (Sample 580-14-2, 130-131 cm), and about $140 \mathrm{~m}$ sub-bottom (between Samples $580-16-2,83-84 \mathrm{~cm}$ and $580-16-4,83-84 \mathrm{~cm}$ ). See legend to Figure 4 for definition of magnetostratigraphic events. 
especially of $D$. seminae and Thalassiosira trifulta, are recognizable; the sharp drops at the upper point are apparently the result of both decreases of Group II diatoms (D. seminae, $T$. trifulta, and $C$. marginatus) and increases of Group I diatoms (mainly of $T$. eccentrica and Thalassionema nitzschioides).

2. Recurrent Group. Group I is dominant in the lower Pliocene and the lower part of the upper Pliocene with two peaks shifted to Group II, at $113.96 \mathrm{~m}$ sub-bottom (Sample 580-13-5, 15-16 cm) and $120.60 \mathrm{~m}$ sub-bottom (Sample 580-14-2, 130-131 cm) (Fig. 5). From $100.84 \mathrm{~m}$ sub-bottom (Sample 580-12-2, 103-104 cm), between the Gauss/Matuyama boundary and the Olduvai Event, upward, Group II dominates over Group I, except for a short interval at about $26.52 \mathrm{~m}$ sub-bottom (Samples $580-4-3,121-122 \mathrm{~cm}$ and $580-4-4,121-122 \mathrm{~cm}$ ) in the lower part of the Brunhes Epoch (Fig. 5). Group II shows a cyclic abundance variation with large fluctuations throughout the Pleistocene.

Group IV occurs almost continuously from $84.91 \mathrm{~m}$ sub-bottom (Sample 580-10-4, 110-111 cm) upward. Its abundance fluctuates and increases during the Brunhes Epoch, but these fluctuations do not coincide with those observed in either the Td values or abundances of $D$. seminae, except at $10.59 \mathrm{~m}$ sub-bottom (Sample 580-2-5, $128-129 \mathrm{~cm}$ ). At $28.02 \mathrm{~m}$ (Sample 580-4-4, 121-122 cm), a Group IV peak corresponds to low Td values, but at this level Group I dominates over Group II as mentioned before.

All these changes in species composition are likely caused by a drop in surface water temperature during a glacial period, except for changes at 4.59 and $26.52 \mathrm{~m}$ sub-bottom, where high temperatures are dominant.

\section{Assemblage Structure}

\section{Site 579}

1. Number of Diatoms. The number of diatoms observed at this site varies with lithologic type (Fig. 4). High concentrations of diatoms, about $5.0 \times 10^{7} / \mathrm{g}$, are generally recognized within the Pliocene clayey siliceous (diatom) ooze. Lower concentrations, generally less than $5.0 \times 10^{7} / \mathrm{g}$, occur throughout the Pleistocene siliceous clay.

2. Productivity. At Site 579, Chaetoceros spores are rare $(\sim 3 \%)$ in the lower Pliocene and increase to a maximum of about $7 \%$ in the upper Pliocene (Fig. 4). The number of Chaetoceros spores fluctuates widely between 6 and $21 \%$ throughout the Pleistocene (Fig. 4).

3. Species Diversity. The diversity increases from about 3.8 in the Nunivac Event to about 13 in the upper part of the Brunhes Epoch, with large fluctuations throughout (Fig. 4). The amplitude of these fluctuations increases from bottom to top of the holes. High diversity values generally correspond to peaks in productivity, as seen in the number of Chaetoceros spores. The maximum diversity value is 22.9 at $8.40 \mathrm{~m}$ sub-bottom (Sample $579-1, \mathrm{CC})$, whereas the minimum diversity is 2.4 at $140.53 \mathrm{~m}$ sub-bottom (Sample 579A-14-3, 2-3 cm).

\section{Site $\mathbf{5 8 0}$}

1. Number of Diatoms. The number of diatoms varies throughout the site (Fig. 5). Generally speaking, the number of diatoms averages about $6.0 \times 10^{7} / \mathrm{g}$ in the upper Pliocene and about $5.0 \times 10^{7} / \mathrm{g}$ in the Pleistocene. The number of diatoms does not seem to vary with lithologic type.

2. Productivity. Fluctuations in the concentration of Chaetoceros spores at Site 580 are similar to those observed at Site 579 (Fig. 5), but the absolute values are only half to one-third of that recognized at Site 579 .

3. Species Diversity. Diversity values at Site 580 do not show downhole fluctuations coincident with other assemblage structure parameters. Diversity is generally lowest in the lower Pleistocene and increases from the lower part of the upper Pleistocene upward, resulting in an average diversity value of 9.4 within most of the Brunhes Epoch (Fig. 5).

The concentration of Chaetoceros spores at both sites shows a trend of upward increase in abundance. The varying concentration of diatoms, on the other hand, describes a different curve. Therefore, diatom productivity is only partially explained by Chaetoceros productivity (Oyashio Current).

The number of diatoms fluctuates more at Site 580 than at Site 579, whereas productivity and the diversity index both fluctuate more at Site 579 than at Site 580. In particular, the productivity at Site 579 is two to three times that at Site 580 . Accordingly, upwelling caused by the shift of the front between the subarctic and subtropic water masses seems to have had a more important effect on the productivity at Site 579 than at Site 580 , especially during glacial periods.

\section{MAJOR PALEOCLIMATIC EVENTS}

Td values fluctuate in similar ways at both Sites 579 and 580 (Fig. 6). These Td values help unravel the paleoceanographic history of the western North Pacific.

A sharp and large drop in Td value at both Site 579 and Site 580 occurred 3.0 m.y. ago (Fig. 6). This decrease in $\mathrm{Td}$ value indicates that the winter surface water temperature fell about $8.9^{\circ} \mathrm{C}$ in $0.3 \mathrm{~m}$.y. at Site 579 and about $11.0^{\circ} \mathrm{C}$ in $0.2 \mathrm{~m} . \mathrm{y}$. at Site 580 . This Td drop marks the boundary between the preglacial and glacial Pliocene previously proposed by Berggren (1972) and Keigwin (1979). No change, however, occurs in recurrent group at this level (Figs. 4 and 5). It is at 2.85 m.y. ago at Site 579 , and at $2.50 \mathrm{~m}$.y. ago at Site 580 , that the surface water temperature falls below that of the present day. Shackleton and Opdyke (1977) also indicated that the scale of glaciations increased about 2.5 m.y. ago. Since then the surface water temperature has never risen to the present level, except at $2.12 \mathrm{~m}$.y. ago when a shortlived comparable surface water temperature is recognized at both sites (Fig. 6). Presumably this level is recognizable as the preglacial/glacial boundary in the western North Pacific. The temperature $2.12 \mathrm{~m}$.y. ago was about $0.5^{\circ} \mathrm{C}$ warmer than today at Site 580 . 

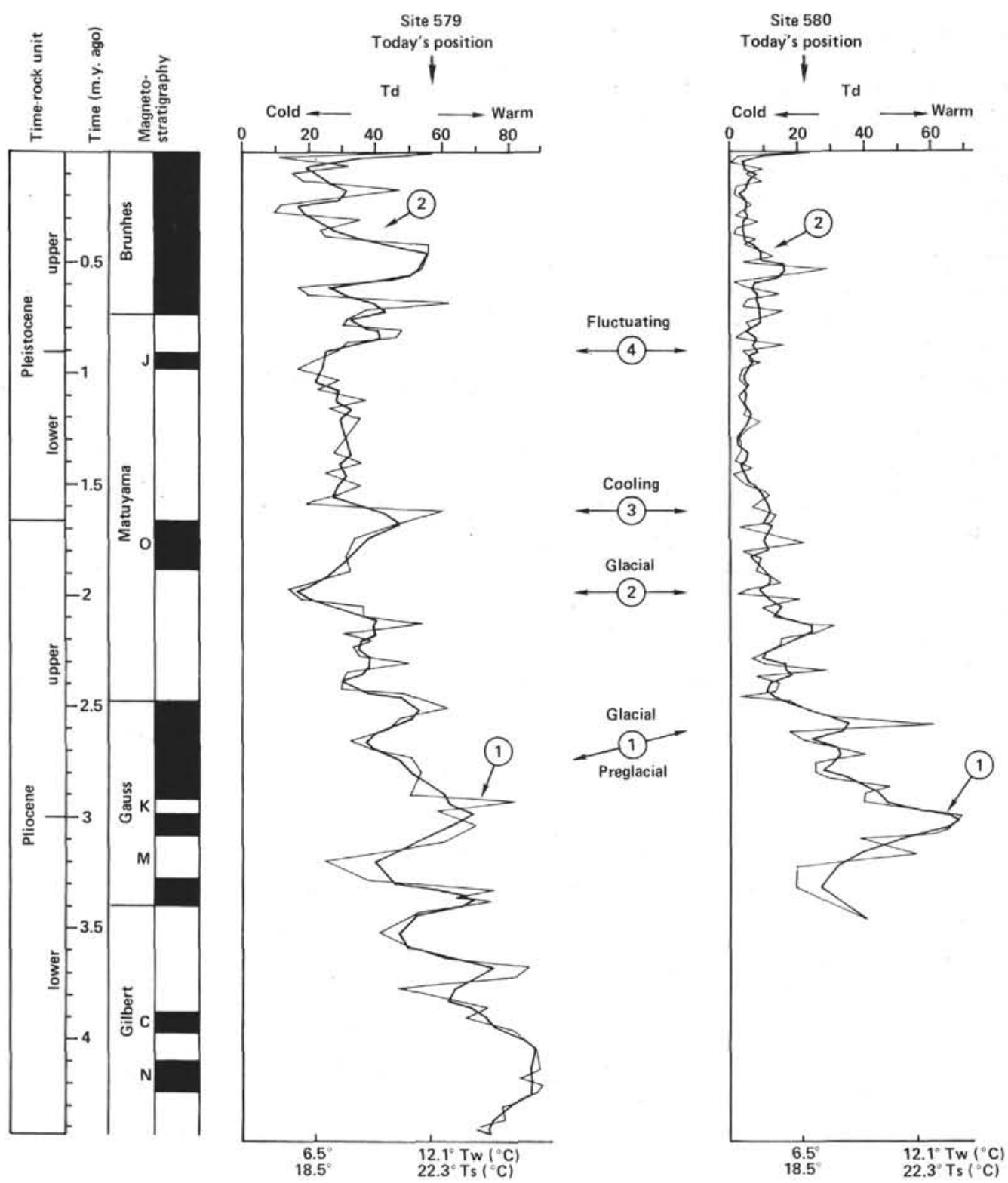

Figure 6. Major paleoclimatic events at Sites 579 and 580. (1) Initiation of glaciation 2.5-2.8 m.y. ago; (2) major glacial event, which is a match for the glacial stages of the Brunhes Epoch, about 2.0 m.y. ago; (3) remarkable cooling about $1.6 \mathrm{~m} . \mathrm{y}$. ago (at the Pliocene/Pleistocene boundary); and (4) beginning of cycles of glacial/interglacial stages about 0.9 m.y. ago (at the early/late Pleistocene boundary). Arrows indicate (1) the beginning of the critical levels where surface water temperature falls below that of the present day about $3.0 \mathrm{~m} . \mathrm{y}$. ago, and (2) the beginning of the smaller amplitude and more rhythmic temperature fluctuations about 0.4 m.y. ago. See legend to Figure 4 for definition of magnetostratigraphic events.

Through the late Pliocene, the surface water temperature kept declining at both sites. At Site 579, the temperature fell an estimated $4.8^{\circ} \mathrm{C}$ from 3.0 to 2.0 m.y. ago; at Site 580 , about $6.7^{\circ} \mathrm{C}$ (Fig. 6). At Site $579,5.4^{\circ} \mathrm{C}$ of the temperature drop occurs immediately before the Olduvai Event 2.0 m.y. ago (Fig. 6). At Site 580, a similar fall in surface water temperature is recognized at the same time. Keigwin (1979) suggested that a major glaciation or bottom-water cooling event occurred between 2.1 and $2.3 \mathrm{~m}$.y. ago on the basis of a significant variation observed in $\delta^{18} \mathrm{O}$ record.

At about the same time as the Olduvai Event, the surface water temperature increased about $7.5^{\circ} \mathrm{C}$ at Site
579. The temperatures at Site 580 seem to stabilize at about $3.2^{\circ} \mathrm{C}$ throughout this period, with some minor fluctuations (Fig. 6).

About 1.6 m.y. ago (at the Pliocene/Pleistocene boundary), a third drop in surface water temperature is recognized. At Site 579, surface water temperature is estimated to have fallen about $5.6^{\circ} \mathrm{C}$ within a short $0.1 \mathrm{~m} . \mathrm{y}$. period. Similarly, the temperature decreased about $2.8^{\circ} \mathrm{C}$ in $0.2 \mathrm{~m}$.y. at Site 580 . After this drop, the surface water temperature did not fluctuate to any recognizable degree. Fluctuations of $\delta^{18} \mathrm{O}$ in oxygen isotope records (Williams et al., 1981) confirm the drop and leveling off of surface water temperature. 
The surface water temperature fluctuates again after a small temperature increase at the Jaramillo Event. This temperature increase begins at about halfway between the Jaramillo Event and the Brunhes Epoch and marks the fourth climatic event (Fig. 6). Note that cycles of glacial/interglacial stages begin at about this level in middle latitudes (Hays and Berggren, 1971). At Site 580, significant decreases in $\mathrm{Td}$ values (i.e., a drop in surface water temperature) are recognized nine times during the Brunhes Epoch. The largest of these decreases occurred at $0.05,0.16-0.19,0.38,0.59$, and 0.70 m.y. ago. Similarly, at Site 579 , large Td decreases occurred at 0.25 , 0.63 , and $0.78 \mathrm{~m} . \mathrm{y}$. ago.

After a sudden increase in Td value near $0.5 \mathrm{~m} . \mathrm{y}$. ago at both sites, the Td values show small amplitude, somewhat rhythmic fluctuations to the present day. This pattern corresponds to that observed in the North Atlantic by Berggren (1972).

\section{CONCLUSIONS}

Both productivity estimated on the basis of the number of Chaetoceros spores and species diversity fluctuate greatly at Site 579 (Fig. 4). Both paleoclimate indexes increase in overall value and in fluctuation amplitude upsection.

A major Td value decrease and the alternation from warm-water diatom Coscinodiscus nodulifer to cold-water diatom Denticulopsis seminae occurred 3.0 m.y. ago at both Sites 579 and 580, but no change in recurrent group occurred (Figs. 4 and 5).

The preglacial/glacial boundary occurred $2.50-2.85$ m.y. ago at about $40^{\circ} \mathrm{N}$ latitude in the western North Pacific (Fig. 6). Since then the surface water temperature has never risen to the present-day level.

The second surface water temperature drop occurred 2.0 m.y. ago at both sites (Fig. 6).

The third drop of temperature occurred about 1.6 m.y. ago (at the Pliocene/Pleistocene boundary; Fig. 6). Recurrent Group IV appears approximately from this level upward.

The surface water temperature did not fluctuate significantly during the lower Pleistocene interval.

Cycles of glacial/interglacial stages begin about halfway between the Jaramillo Event and the Brunhes Epoch. At Site 580, surface water temperature decreases occurred nine times during the Brunhes Epoch (Figs. 5 and 6). An interglacial stage occurred about $0.5 \mathrm{~m}$.y. ago at both Sites 579 and 580 (Fig. 6).

Td values from 0.5 m.y. ago to the present show smaller amplitudes and more rhythmic fluctuation than before (Fig. 6).

\section{ACKNOWLEDGMENTS}

This study builds on the fundamental work on diatoms initiated by Dr. Taro Kanaya, who had to retire in the middle of his active academic career, which had such a promised start.

I would like to thank the reviewers, Drs. Constance A. Sancetta and Howard E. Harper, and especially Drs. Audrey A. Wright, Lloyd
H. Burckle, and Tsunemasa Saito, who made suggested English revisions and scientific comments.

\section{REFERENCES}

Berggren, W. A., 1972. Late Pliocene-Pleistocene glaciation. In Laughton, A. S., Berggren, W. A., et al., Init. Repts. DSDP, 12: Washington (U.S. Govt. Printing Office), 953-963.

Burckle, L. H., and Opdyke, N. D., 1977. Late Neogene diatom correlations in the circum-Pacific. In Saito, T. and Ujiié, H. (Eds.), Proceedings of the First International Congress on Pacific Neogene Stratigraphy, Tokyo, 1976: Tokyo (Kaiyo Shuppan), pp. 255-284.

Dodimead, A. J., Favorite, F., and Hirano, T., 1963. Review of oceanography of the subarctic Pacific region. International North Pacific Fisheries Commission, Bull., Pt. II, 13:1-195.

Donahue, J. G., 1970. Pleistocene diatom as climatic indicators in North Pacific sediments. In Hays, J. D. (Ed.), Geological Investigation of the North Pacific. Mem. Geol. Soc. Am., 126:121-138.

Hasle, G. R., 1976. The biogeography of some marine planktonic diatoms. Deep-Sea Res., 23:319-338.

Hays, J. D., and Berggren, W. A., 1971. Quaternary boundaries and correlations. In Funnell, B. M., and Riedel, W. R. (Eds.), The Micropaleontology of Oceans: London (Cambridge Univ. Press), pp. 669-692.

Ikeya, N., 1971. Species diversity of benthonic foraminifera, off the Shimokita Peninsula, Pacific coast of north Japan. Rec. Oceanogr. Works in Japan, 11:27-37.

Japan Oceanographic Data Center, 1978. Marine Environment Atlas, Northwestern Pacific Ocean (Vol II) (Seasonal and Monthly): Tokyo (Japan Hydrogr. Assoc.).

Jousé, A. P., Kozlova, O. G., and Muhina, V. V., 1971. Distribution of diatoms in the surface layer of sediment from the Pacific Ocean. In Funnell, B. M. and Riedel, W. R. (Eds.), The Micropaleontology of Oceans: London (Cambridge Univ. Press), pp. 263-269.

Kanaya, T., and Koizumi, I. 1966. Interpretation of diatom thanatocenoses from the North Pacific applied to a study of core V20-130 (Studies of a deep-sea core V20-130. Part IV). Sci. Rep. Tohoku Univ. Ser. 2, 37:89-130.

Keigwin, L. D., Jr., 1979. Late Cenozoic stable isotope stratigraphy and paleoceanography of DSDP sites from the east equatorial and central North Pacific Ocean. Earth Planet. Sci. Lett., 45:361-382.

Keller, G., 1979. Late Neogene paleoceanography of the North Pacific DSDP Sites 173, 310, and 296. Mar. Micropaleontol., 4:159-172.

Sancetta, C., 1982. Distribution of diatom species in surface sediments of the Bering and Okhotsk seas. Micropaleontology, 28: 221-257.

Shackleton, N. J., and Opdyke, N. D., 1976. Oxygen-isotope and paleomagnetic stratigraphy of Pacific core V28-239: Late Pliocene to latest Pleistocene. In Cline, R. M., and Hays, J. D. (Eds.), Investigation of Late Quaternary Paleoceanography and Paleoclimatology, Geol. Soc. Am. Mem., 145:449-464.

1977. Oxygen isotope and paleomagnetic evidence for early Northern Hemisphere glaciation. Nature (London), 270:216-219.

Simpson, E. H., 1949. Measurement of diversity. Nature (London), 163:688

Venrick, E. L., 1971. Recurrent groups of diatom species in the North Pacific. Ecology, 52:614-625.

Vincent, E., 1975. Neogene planktonic foraminifera from the Central North Pacific Leg 32, Deep Sea Drilling Project. In Larson, R. L., Moberly, R., et al., Init. Repts. DSDP, 32: Washington (U.S. Govt. Printing Office), 765-791.

Williams, D. F., Moore, W. S., and Fillon, R. H., 1981. Role of glacial Arctic Ocean ice sheets in Pleistocene oxygen isotope and sea level records. Earth Planet. Sci. Lett., 56:157-166.

Date of Initial Receipt: 4 January 1984

Date of Acceptance: 14 May 1984 